\title{
The Economic Implications of Wind Energy and Solar Photovoltaic System Utilization for Electricity Generation in Nigeria
}

\author{
Ebigenibo Genuine Saturday*, Oluwasanmi Adeshina Aderibigbe
}

Department of Mechanical Engineering, University of Port Harcourt, PMB 5323, Choba, Port Harcourt, Nigeria

DOI: $\underline{10.36348 / \text { sjet.2020.v05i12.006 }}$

| Received: 19.10.2020 | Accepted: 04.11.2020 | Published: 30.12 .2020

*Corresponding author: Ebigenibo Genuine Saturday

\section{Abstract}

The economic implications of using solely wind energy or solar photovoltaic (PV) system for electric power generation in Nigeria is considered in this work. Twelve states from the six geopolitical zones of Nigeria were used as case studies for wind energy utilization while 6 states were used for solar energy usage. Wind speed and solar radiation data for the state capitals were used for the analysis. The net present value (NPV) and the levelized cost of electricity (LCOE) for each state for a project lifespan of 20 years was estimated for each power system in the various states using discount rate equivalent to the prevailing interest rate $(16 \%)$ in Nigeria and lower values. At $16 \%$ discount rate for wind energy system, only 4 states gave positive NPV while at $8 \%$ discount rate 9 states have positive NPVs. For the solar PV system, the NPVs are negative for all the 6 states at $16 \%$ discount rate while only one location with the highest average annual solar radiation of $6.4 \mathrm{kWh} / \mathrm{m}^{2}$ day gave positive NPV at $8 \%$ discount rate. The LCOE is smaller for wind energy systems in many of the locations considered. When energy is not discounted, the highest and the lowest LCOE for wind energy system are $0.1937 \$ / \mathrm{kWh}$ and $0.0167 \$ / \mathrm{kWh}$ respectively while the respective values for solar PV system are 0.0615 $\$ / \mathrm{kWh}$ and $0.0415 \$ / \mathrm{kWh}$. The LCOE when energy is discounted is higher and the average value obtained either system is higher than the price of electricity in Nigeria but lower than the electricity price in the UK and the USA. Thus for wind and solar PV systems to be more economically viable for electricity generation in many locations in Nigeria, the current installation costs should come down and or the price of electricity should go up.

Keywords: Discount rate, Levelized cost of electricity, Net present value, Solar photovoltaic, Solar radiation, Wind energy.

Copyright (C) 2020 The Author(s): This is an open-access article distributed under the terms of the Creative Commons Attribution 4.0 International License (CC BY-NC 4.0) which permits unrestricted use, distribution, and reproduction in any medium for non-commercial use provided the original author and source are credited.

\section{NOMENCLATURE}

\begin{tabular}{|l|l|}
\hline $\mathrm{A}$ & area of turbine blades, area covered by solar panels, $\mathrm{m}^{2}$ \\
\hline$A C_{O \& M}$ & annual operations and maintenance cost, $\$$ \\
\hline$A E$ & annual estimated solar energy output, $\mathrm{kWh}$ \\
\hline $\mathrm{AR}$ & annual revenue, $\$$ \\
\hline$C e$ & cost of electricity, $\$ / \mathrm{kWh}$ or $\mathrm{kWh}$ \\
\hline$C_{i}$ & installation cost, $\$ / \mathrm{kW}$ \\
\hline$C_{m}$ & operations and maintenance cost, $\$ / \mathrm{kWh}$ \\
\hline$C f$ & capacity factor for wind energy system, dimensionless \\
\hline$C f_{s}$ & capacity factor for solar PV module, dimensionless \\
\hline$D$ & rotor diameter, $\mathrm{m}$ \\
\hline$E_{a}$ & energy available in the wind per unit time, $\mathrm{W}$ \\
\hline$E_{e}$ & energy extractable per unit time, $\mathrm{W}$ \\
\hline$E_{i n}$ & energy installed, $\mathrm{kWh}$ \\
\hline $\mathrm{ED}$ & energy demand, $\mathrm{kWh}$ \\
\hline$E D_{r s}$ & energy demand of rivers state, $\mathrm{kWh}$ \\
\hline$E D_{s}$ & energy demand of the various $\mathrm{states}, \mathrm{kWh}$ \\
\hline
\end{tabular}




\begin{tabular}{|l|l|}
\hline$G$ & average daily global irradiance, $\mathrm{kWh} / \mathrm{m}^{2}$.day \\
\hline$G D P_{r_{S}}$ & gross domestic product of rivers state, $\$$ or $\$$ \\
\hline$G D P_{S}$ & gross domestic product of the various states, $\mathrm{N}$ or $\$$ \\
\hline$I C$ & total installation cost, $\$$ \\
\hline $\mathrm{LCOE}$ & levelized cost of electricity, $\$ / \mathrm{kWh}$ \\
\hline$n$ & number of turbines to be installed, dimensionless \\
\hline NACF & net annual cash flow, $\$$ \\
\hline NPV & net present value, $\$$ \\
\hline$P_{k}$ & peak power or Watt peak, $\mathrm{kWh}$ \\
\hline$P_{r}$ & performance ratio, dimensionless \\
\hline$P_{R}$ & turbine rated power, $\mathrm{W}$ \\
\hline POP & population, dimensionless \\
\hline$P O P_{r S}$ & population of rivers state, dimensionless \\
\hline$P O P_{S}$ & population of the various states, dimensionless \\
\hline PV & Photovoltaic, short form \\
\hline$r$ & discount rate, $\%$ \\
\hline TLCC & total life cycle cost, $\$$ \\
\hline TLEP & total life cycle energy production, $\mathrm{MWh}$ \\
\hline$v$ & wind speed, $\mathrm{m} / \mathrm{s}$ \\
\hline$v_{10}$ & wind speed at 10 metres height, $\mathrm{m} / \mathrm{s}$ \\
\hline$v_{z}$ & wind speed at altitude $\mathrm{z}, \mathrm{m} / \mathrm{s}$ \\
\hline$z$ & altitude at which wind energy is extracted, $\mathrm{m}$ \\
\hline$\rho$ & density of air, $\mathrm{kg} / \mathrm{m}^{3}$ \\
\hline
\end{tabular}

\section{INTRODUCTION}

Energy is of critical importance to the growth and development of any modern nation. The demand for energy is rising in Nigeria. Although energy has been generated for over a century, energy demand in Nigeria presently is far more than the supply. Using Model for Analysis of Energy Demand, a model used to evaluate future energy demands based on medium to long term scenarios of socioeconomic, technological, and demographic development, it was observed that Nigeria's economy needed approximately 131,122MW of electricity to function properly as at 2017 [1]. The energy demand actually increases with the population and industrial development. Unfortunately, as at today, Nigeria has installed electrical power capacity of little above 12,000 MW, national grid capacity of about 7000 MW and average power production which is around 4000 MW. Although new power stations are being undertaken, the present power output is less than half of the total installed capacity as some plants are nonfunctional while many of those in operation are operating below their installed capacities. This implies the national grid will not be able to handle the total installed power if all the plants are operational and operates at the installed capacities. This is one major reason for the call for off-grid electricity generation in Nigeria.

Apparently, renewable energy resources for electrical power production, such as wind energy and solar photovoltaic (PV) sources can be easily operated off-grid. There are thus several efforts at estimating the wind energy potentials [2-4] and the solar energy potentials in different locations of Nigeria [5-7]. Many other researchers have actually taken a view at the renewable energy potentials in Nigeria. Vincent-Akpu [8] explored the renewable energy potentials in Nigeria together with the level of energy utilization and the factors working against the development and utilization of renewable energy. Also, the challenges in utilizing renewable energy for electricity generation in Nigeria have been studied [9]. In examining the sustainable energy development in Nigeria, Emodi and Boo [10] also investigated the renewable energy potentials in different locations of the country. In studying the renewable energy potentials in Nigeria, Bamisile et al., [11] paid specific attention on the position of solar energy by looking at the past, the present and the future usages. As many rural communities in Nigeria are not connected to the national electricity grid, studies aimed at the utilization of renewable energy to meet the developmental needs of rural communities in Nigeria have also been carried out $[12,13]$. The demand for energy in Nigeria far outweighs the supply. Thus, many other studies are towards sustainable energy development and having access to electricity in Nigeria [14-16].

Hydroelectric power which is the most widely used renewable energy source today in terms of installed capacity has been in use in Nigeria. The electricity generated from the hydroelectric power sources is connected to the national grid. Nigeria's hydroelectric reserve is estimated to be 11,250 MW for large hydropower and 3,500 MW for small hydropower [17]. The small hydropower can be easily harnessed off-grid if tapped. A number of researchers actually 
focussed on small hydropower systems since they can be easily harnessed with respect to technology, time and cost [18-20]. In terms of solar energy and wind energy which are considered in this work, Nigeria receives 3.5 $-7.0 \mathrm{kWh} / \mathrm{m}^{2}$ per day of solar radiation and roughly 2 to $4 \mathrm{~m} / \mathrm{s}$ of wind speed at $10 \mathrm{~m}$ height [17]. Higher wind speeds are obtainable at higher heights while offshore wind speeds are generally greater. The available wind energy and solar energy potentials are more than enough to meet the electrical energy demands of Nigeria.

The Nigerian government, through the rural electrification agency (REA) launched Energizing Economies Initiative (EEI) in 2017 to provide clean and affordable electricity off-grid (with $70 \%$ renewable energy based) for over 100,000 business clusters as part of the nation's Micro, Small, Medium Enterprise (MSMEs) programme in order promote economic growth [21]. The programme has led to the provision of off-grid power for a number of major markets and business complexes exploiting mainly solar PV system in many of the places. The power produced from the existing power stations falls short of the demand as earlier pointed out. Also, the national grid is not able to handle the total power requirement; hence, off-grid power production using renewable energy has been strongly advocated [22-24]. Expanding the existing national grid appears cumbersome and unrealistic; hence, off-grid is advocated. Also, clean energy is being looked at in the global stage. The renewable energy sources are thus being embraced for off-grid power solution in Nigeria. Solar and wind energies are the two most welcomed renewable energy sources for off-grid electricity generation in Nigeria. In calling for solar energy and wind energy sources for electricity generation, little or no attention is paid to the economic implications of their utilization in Nigeria. In this work therefore, the economic implications of the utilization of solar PV and wind energy for electricity generation in selected states in Nigeria is carried out.

\section{MATERIALS AND METHODS}

This research entails determining the economic implications of renewable energy utilization for electricity generation in Nigeria, specifically wind and solar energy. A total of 12 states from the 6 geopolitical zones of Nigeria were used in determining the economic implications of using solely wind energy to meet the energy demand of each state. The relevant data obtained from the state capitals are considered for the analysis. The 12 states for wind energy utilization are Lagos, Oyo, Calabar, Rivers, Enugu, Imo, Kano, Katsina, Niger, Kwara, Bornu and Plateau states. The same was done for solar energy, using 6 states (Oyo, Rivers, Enugu, Sokoto, Kwara and Bornu). States from the 6 geopolitical zones in the country with the highest relative wind speed were chosen for the wind power analysis while those with the highest solar radiation were selected for solar PV system analysis. The energy demands of each of the states were first estimated, and then the respective energy potential was estimated. This was then followed by the economics of providing the required energy based on the demand.

\section{Estimation of Energy Demand of the States}

Before determining the total amount of energy to be installed for a particular location, the energy demand of each state must be ascertained. There is no data about the energy demand of the states. But this is estimated here from the population, the gross domestic product (GDP) and the energy demand value of any state which value is known. The energy demand of Rivers state is used as a basis for this estimation. The energy demand for Rivers state from 2016 - 2025 has been estimated, and the value for 2020 using least square model in Reference [25] is 1035.5 MW. Energy demand increases with both population and GDP. A joint proportionality relationship between the energy demand and the population plus the GDP of two states is formulated as,

$$
E D_{s}=\frac{G D P_{s}}{G D P_{r s}} \times \frac{P O P_{s}}{P O P_{r s}} \times E D_{r s}
$$

Where $E D_{s}, G D P_{s}$ and $P O P_{s}$ are the energy demand, the GDP and the population of the state which energy demand is to be estimated while $E D_{r s}, G D P_{r s}$ and $P O P_{r s}$ are the respective values for Rivers state which are known.

\section{Estimation of Available Wind Power}

Three parameters are required to estimate the wind power available for a particular site to be extracted by a wind turbine: the area of the turbine blades (A), the site air density $(\rho)$ and the wind speed $(v)$. The energy available in the wind $\left(E_{a}\right)$ to be extracted is,

$$
E_{a}=\frac{1}{2} \times \rho \times A \times v^{3}
$$

Equation (1) represents the energy available in the wind for the given blade area. The actual energy extracted by the turbine is estimated through the capacity factor $(C f)$. The capacity factor is the ratio of the actual power produced over a given period of time to the hypothetical maximum capacity of the turbine. The extractable energy $\left(E_{e}\right)$ from the turbine in $\mathrm{MW}$ is thus given as,

$$
E_{e}=P_{R} \times C f
$$

The capacity factor can be expressed through different methods; here Raleigh approach is adopted and it is given as [26],

$$
C f=0.087 \times v-\frac{P_{R}}{D^{2}}
$$

Where $P_{R}$ is the rated power of the turbine in kilo Watts or Mega Watts and $D$ is the rotor diameter in meters. 
AN Bonus wind turbine with $1 \mathrm{MW}$ rated power, rated wind speed of $15 \mathrm{~m} / \mathrm{s}$, cut in speed of 3 $\mathrm{m} / \mathrm{s}$ and rotor diameter $60 \mathrm{~m}$ is chosen to extract power from the wind in the various states considered. The capacity factor of the wind in the various locations is estimated using the parameters of this wind turbine. Wind speed at turbine hub height of $60 \mathrm{~m}$ is estimated for analysis using Equation (5) [26],

$$
\frac{v_{z}}{v_{10}}=\left(\frac{z}{10}\right)^{0.3}
$$

Where $z$ is the height at which the wind speed is to be estimated, $v_{z}$ is the wind speed at height $z$ and $v_{10}$ is the wind speed estimated at height $10 \mathrm{~m}$. The exponent in Equation (5) usually varies between 1/7 and $1 / 2 ; 1 / 7$ is adopted in this work.

The total wind energy that must be installed to produce the energy demand of a state would be the ratio of the energy demand of the state to the capacity factor of wind energy in that state. This is given by Equation (6),

$$
E_{\text {in }}=\frac{E D_{S}}{C F}
$$

Where $E_{\text {in }}$ is the total installation energy and $E_{e d}$ is the total energy demand of the state. If wind turbines of same type are to be installed, the total number of turbines $n$ will be,

$$
n=\frac{E_{\text {in }}}{E_{e}}
$$

\section{Estimation of Available Solar Energy}

To estimate the potential electricity generation from solar energy for selected locations, three parameters are required; the yearly average daily global irradiance, the performance ratio $\left(P_{r}\right)$ and the peak power $\left(P_{k}\right)$ of the solar PV module (also known as Watt peak). The performance ratio is the measure of the performance of a PV system taking into account environmental factors like temperature, and irradiation. Peak power or (Watt peak, Wp; kilowatt peak, $\mathrm{kWp}$, etc.) is the maximum electricity a solar panel can supply per unit area under standard test conditions. The total annual estimated energy output $(A E)$ of a solar PV system is expressed as [27],

$$
A E=365 \times P_{r} \times G \times P_{k}
$$

Where $G\left(\mathrm{kWh} / \mathrm{m}^{2} /\right.$ day $)$ is the average daily global irradiance of the site and 365 is the number of days in a year. The extractable solar energy per unit time $E_{a}$ of a selected location is,

$$
E_{a}=\frac{A E}{8760}
$$

Where 8760 is the number of hours per year. The performance ratio, $P_{r}$ is taken as 0.75 .
Since the capacity factor is the total amount of power during a period of time divided by the amount of power the plant would have produced at full capacity, the solar capacity factor can be calculated using Equation (10),

$$
C f_{s}=\frac{E_{a}}{P_{k}}
$$

Where $C f_{s}$ is the capacity factor of the solar PV module. From Equations (8) to (10), the capacity factor can be expressed as,

$$
C f_{s}=\frac{E_{a}}{P_{k}}=\frac{365 \times P_{r} \times G}{8760}
$$

\section{Estimation of Total Solar Farm Installation Energy}

Since the power available is the product of the capacity factor and peak power, the total solar energy to be installed in order to generate the required energy demand can be calculated from Equation (12),

$$
E_{\text {in }}=\frac{E D_{s}}{C f_{s}}
$$

The total area $(A)$ to be covered by the solar panels depends on the watt peak and the energy to be installed, and it can be expressed as,

$$
A=\frac{E D_{S}}{P_{K}}
$$

Thus, a solar PV module with greater Watt peak value will require smaller area for installation of the solar panels. Peak power of $1 \mathrm{kWp}$ is assumed for the solar PV module in this work.

\section{Economic Analysis}

The viability of wind energy plants depends on its ability to generate energy at a low operating cost. There are several factors that affect the unit energy cost of electricity production using wind energy which includes investment cost, operation and maintenance cost, average wind speed, turbine lifetime, and discount rate (DR) [28]. There are many methods of judging the economic viability of any power plant system or project. The Net Present Value (NPV) and the levelized cost of electricity (LCOE) methods were adopted in this work. The NPV of any project can be expressed as,

$$
N P V=\sum_{i=1}^{n} \frac{N A C F}{(1+r)^{i}}-I C
$$

Where $N A C F$ is the net annual cash, IC is the installation cost, $n$ is the lifespan of the project (wind turbine plant or solar PV system in this case), $r(\%)$ is the discount rate. Life span of 20 years is assumed in this work. The net annual cash flow for year is expressed as,

$$
N A C F=A R-A C_{O \& M}
$$

Where $A R$ is the annual revenue and $A C_{O \& M}$ is the annual operations and maintenance cost, both assumed to be constant for the lifespan of the project. The annual revenue, the annual operations and 
maintenance costs and the installation costs of the wind energy system and solar PV system are to be estimated.

The LCOE is expressed as [29],

$$
L C O E=\frac{T L C C}{T L E P}
$$

Where TLCC is the present value of the total life cycle cost and TLEP is the total life cycle energy production (either brought to the present or not). The TLCC can be expressed as,

$$
T L C C=I C+\sum_{i=1}^{n} \frac{A C_{O \& M}}{(1+r)^{-i}}
$$

Where $\mathrm{n}$ is the lifespan of the project and $\mathrm{r}$ is the discount factor. The TLEP on the other hand can be expressed as,

$$
T L E P=E D \times n
$$

Equation (18) is used when the value of the energy produced is not brought to the present. If brought to the present, the TLEP is expressed as,

$$
T L E P=\sum_{i=1}^{n} \frac{E D}{(1+r)^{-i}}
$$

The LCOE is presented for both cases in this work.

\section{Estimation of Revenue}

The revenue comes from the sale of electricity assuming all energy being produced is sold. The cost of electricity in Nigeria depends on the usage and an average price based on the multi order tariff (MYTO) [30] was used in this work. The price used here is equivalent to $0.097 \$$ per kilowatt-hour. The total revenue gotten from a wind farm or solar PV system can be expressed as,

$$
A R=E D_{s} \times 8760 \times C e
$$

where $C e$ is the cost of electricity in $\$ / \mathrm{kWh}$ and 8760 is the number of hours per year.

\section{Estimation of Installation Costs}

The installation cost of either a wind farm or solar PV system is,

$$
I C=E_{\text {in }} \times C_{i}
$$

where $E_{\text {in }}$ (in $\mathrm{kW}$ ) is the amount of energy to be installed and $C_{i}$ is the cost of installation in $\$ / \mathrm{kW}$. The installation cost of onshore wind energy system is between $\$ 1,200$ per $\mathrm{kW}$ and $\$ 1,600$ per $\mathrm{kW}$ while the value for offshore wind energy system is much higher at [31]. The cost of installing utility-scale PV system is $\$ 3.11$ per Watt for residential systems and $\$ 2.10$ per Watt for commercial systems. For fixed-tilt utility-scale systems, the value is as low as $\$ 1.44$ per Watt [32]. The value for utility-scale system is adopted in this work.

\section{Estimation of Annual Operations and Maintenance Costs}

The annual operations and maintenance cost for wind or solar PV system can be expressed as,

$$
\begin{aligned}
& A C_{O \& M}=E_{\text {in }} \times C_{m} \times 8760 \\
& \ldots \ldots \ldots \ldots \ldots \ldots \ldots \ldots \ldots \ldots \ldots \ldots \ldots
\end{aligned}
$$

where $C_{m}$ is the operations and maintenance cost in $\$ / \mathrm{kWh}$. The Ukrainian Wind Energy Association obtained an approximate value of operations and maintenance cost of wind turbines from using data from several operators and component providers as $\$ 0.027 / \mathrm{kWh}$ (\$27/MWh) [33]. The maintenance cost of utility-scale solar farms is much lower at $\$ 13$ per KW$\mathrm{yr}$ [32]. This is equivalent to $\$ 0.001454$ per $\mathrm{kWh}$. These values are adopted in this work.

\section{Parametric Analysis}

The various cost components either for wind turbine system or solar PV system are not static. Also, the cost of electricity varies based on the users; meaning the revenue accruable depends on the end users of the electricity produced. Discount rate is another parameter that varies. In Nigerian situation, interest rate based on the Central Bank of Nigeria is around $16 \%$, but power projects are usually executed at much lower discount rates. Thus, parametric analysis is also carried out to see how various cost components affect the NPV as well as the LCOE from the two power systems considered in this work. Parametric analysis is carried out for Lagos state for wind energy system and Rivers state for solar PV system.

\section{RESULTS AND DISCUSSIONS}

Tables-1 presents the input data used for the analysis. 


\begin{tabular}{|c|c|c|c|c|}
\hline \multicolumn{5}{|c|}{ Table-1: Input parameters for the analysis } \\
\hline \multirow[b]{2}{*}{ States } & \multicolumn{4}{|l|}{ Parameters } \\
\hline & $\begin{array}{l}\text { Annual wind speed at } \\
10 \mathrm{~m} \text { height, } \\
v(\mathrm{~m} / \mathrm{s})[27]\end{array}$ & $\begin{array}{l}\text { Yearly average daily radiation , Ghi } \\
\left(\mathrm{kWh} / \mathrm{m}^{2} / \text { day) [27] }\right.\end{array}$ & $\begin{array}{l}\text { Population } \\
{[34]}\end{array}$ & $\begin{array}{l}\text { Gross Domestic Product } \\
\text { (GDP), \$ [34] }\end{array}$ \\
\hline Lagos & 4.69 & $\mathrm{n} / \mathrm{a}$ & $\underline{13,380,099}$ & $\underline{28,982,026,725}$ \\
\hline Oyo & 3.86 & $4.71\left(14^{\circ}\right)$ & $\underline{8,392,589}$ & $14,359,592,133$ \\
\hline $\begin{array}{l}\text { Cross } \\
\text { River }\end{array}$ & 4.60 & $\mathrm{n} / \mathrm{a}$ & $\underline{4,097,147}$ & $\underline{8,201,773,224}$ \\
\hline Rivers & 3.30 & $4.31\left(11^{\circ}\right)$ & $\underline{7,817,865}$ & $18,655,004,840$ \\
\hline Enugu & 5.73 & $4.82\left(12^{\circ}\right)$ & $4,683,887$ & $4,115,415,401$ \\
\hline Imo & 2.80 & $\mathrm{n} / \mathrm{a}$ & $\underline{5,766,234}$ & $13,492,238,667$ \\
\hline Kano & 9.39 & $\mathrm{n} / \mathrm{a}$ & $13,969,084$ & $\underline{13,611,262,055}$ \\
\hline Katsina & 7.45 & $\mathrm{n} / \mathrm{a}$ & $\underline{8,315,581}$ & $5,337,228,655$ \\
\hline Sokoto & $\mathrm{n} / \mathrm{a}$ & $5.34\left(15^{\circ}\right)$ & $5,307,155$ & $\overline{5,090,063,046}$ \\
\hline Niger & 5.36 & $\mathrm{n} / \mathrm{a}$ & $\underline{5,947,318}$ & $5,658,258,371$ \\
\hline Kwara & 5.04 & $5.23\left(14^{\circ}\right)$ & $3,390,330$ & $3,742,563,051$ \\
\hline Bornu & 5.22 & $6.4\left(16^{\circ}\right)$ & $6,272,546$ & $\underline{4,902,895,994}$ \\
\hline Plateau & 9.47 & $\mathrm{n} / \mathrm{a}$ & $4,433,502$ & $4,964,050,182$ \\
\hline
\end{tabular}

$\mathrm{n} / \mathrm{a}=$ not applicable. The yearly average daily radiations are given at the point of optimal inclination angle in brackets.

The results of the wind energy parameters of the 12 locations considered are presented in Table-2. Kano state goes with the highest wind speed, hence it has the highest capacity factor. The installed energy depends on the energy demand and the capacity factor.
The installed energy is closer to the energy demand if the capacity factor is closer to unity. Rivers state with very low capacity factor has the installed energy far above the energy demand.

Table-2: Wind energy parameters of the selected states

\begin{tabular}{|l|l|l|l|l|l|}
\hline States & $\begin{array}{l}\text { Wind speed at 60 } \\
\mathbf{m}, \mathbf{m} / \mathbf{s}\end{array}$ & $\begin{array}{l}\text { Capacity } \\
\text { factor }\end{array}$ & $\begin{array}{l}\text { Energy demand, } \\
\text { MW }\end{array}$ & $\begin{array}{l}\text { Installed wind } \\
\text { energy, MW }\end{array}$ & $\begin{array}{l}\text { Number of } \\
\text { turbine units }\end{array}$ \\
\hline Lagos & 6.06 & 0.2493 & 2753.31 & 11045.13 & 11045 \\
\hline Oyo & 4.99 & 0.1560 & 855.67 & 5484.91 & 5485 \\
\hline $\begin{array}{l}\text { Cross } \\
\text { River }\end{array}$ & 5.94 & 0.2392 & 238.59 & 997.61 & 998 \\
\hline Rivers & 4.26 & & & & \\
\hline Enugu & 7.40 & 0.0931 & 1035.50 & 11125.83 & 11126 \\
\hline Imo & 3.62 & 0.3662 & 136.86 & 373.79 & 374 \\
\hline Kano & 12.13 & 0.0369 & 552.39 & 14976.97 & 14977 \\
\hline Katsina & 9.62 & 0.7775 & 1350.00 & 1736.43 & 1736 \\
\hline Niger & 6.92 & 0.5594 & 315.12 & 563.27 & 563 \\
\hline Kwara & 6.51 & 0.3246 & 238.93 & 736.14 & 736 \\
\hline Bornu & 6.74 & 0.2886 & 90.09 & 312.15 & 312 \\
\hline Plateau & 12.23 & 0.3088 & 218.35 & 707.02 & 707 \\
\hline
\end{tabular}

The suitability of wind energy usage may be judged with the economic parameters. The NPV and the LCOE for project life of 20 years are presented in Table-3 for $16 \%$ and $8 \%$ discount rates. At $16 \%$ discount rate, only three locations have positive NPVs; these are the states with the highest capacity factors where the installed energy is closest to the energy demand. The LCOE from these three locations are the lowest both at $16 \%$ and $8 \%$ dicount rates. The LCOEs obtained at $8 \%$ discount rate are higher than those obtained at $16 \%$ discount rate when energy is not discounted, suggesting that energy is cheaper at higher discount rate which is not true. When energy is discounted, LCOEs obtained at $8 \%$ discount rate are lower. Thus, LCOE with energy discounted is the appropriate way to go. 
Ebigenibo Genuine Saturday \& Oluwasanmi Adeshina Aderibigbe; Saudi J Eng Technol, Dec, 2020; 5(12): 524-535

\begin{tabular}{|l|l|l|l|l|l|l|}
\hline \multirow{2}{*}{ Tatate } & NPV $($ Million \$) & \multicolumn{2}{l|}{ LCOE (\$/kWh) } & At 16\% DR \\
\cline { 2 - 7 } & & & At 8\% DR & \\
\cline { 3 - 7 } & At 8\% DR & At 16\% DR & Energy und. & Energy dis. & Energy und. & Energy dis \\
\hline Lagos & 3310.95 & -3251.06 & 0.0407 & 0.0830 & 0.0355 & 0.1197 \\
\hline Oyo & -1433.83 & -3473.16 & 0.0572 & 0.1164 & 0.0519 & 0.1751 \\
\hline Cross River & 238.34 & -330.30 & 0.0419 & 0.0853 & 0.0366 & 0.1236 \\
\hline Rivers & -7120.98 & -9588.90 & 0.0868 & 0.1769 & 0.0816 & 0.2753 \\
\hline Enugu & 374.88 & 48.69 & 0.0320 & 0.0651 & 0.0267 & 0.0901 \\
\hline Imo & -14648.97 & -15965.48 & 0.1990 & 0.4053 & 0.1937 & 0.6535 \\
\hline Kano & 6038.46 & 2820.99 & 0.0221 & 0.0449 & 0.0168 & 0.0567 \\
\hline Katsina & 1219.97 & 468.94 & 0.0255 & 0.0519 & 0.0202 & 0.0683 \\
\hline Niger & 554.14 & -15.31 & 0.0344 & 0.0700 & 0.0291 & 0.0982 \\
\hline Kwara & 167.44 & -47.27 & 0.0370 & 0.0753 & 0.0317 & 0.1071 \\
\hline Bornu & 465.30 & -55.11 & 0.0354 & 0.0722 & 0.0302 & 0.1018 \\
\hline Plateau & 701.70 & 329.28 & 0.0220 & 0.0447 & 0.0167 & 0.0564 \\
\hline
\end{tabular}

dis. $=$ discounted; und $=$ undiscounted

Figure-1 shows the variation of LCOE with discount rate for Lagos state. The LCOE when energy is discounted is greater than the LCOE when energy is not discounted. The LCOE increases more greatly with discount rate when energy is discounted than the way it decreases with discount rate when energy is not discounted.

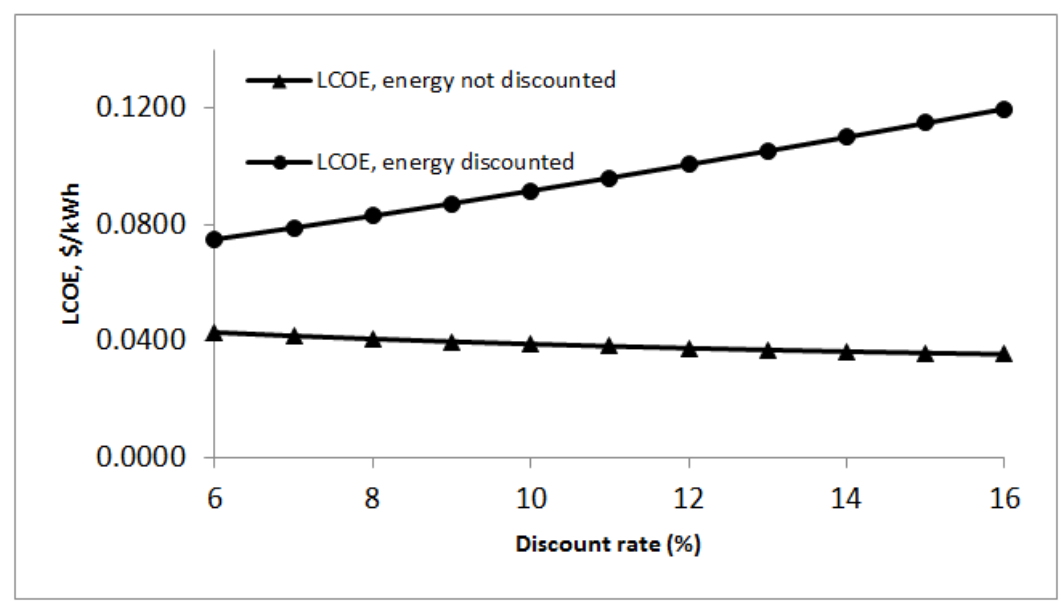

Fig-1: LCOE against discount rate

The variation of the NPV with installation cost, operation and maintenance cost, discount rate and price of electricity (in Nigerian Naira) for Lagos state are shown in Figures 2, 3, 4 and 5 respectively.

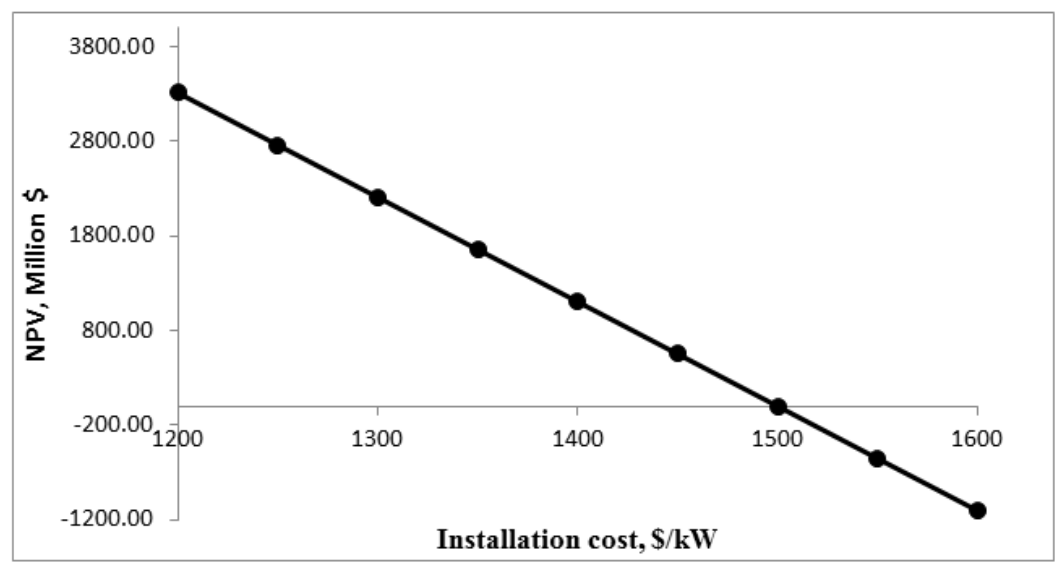

Fig-2: NPV against installation cost at $8 \%$ discount rate 
Using electricity price of $35 \mathrm{~N} / \mathrm{kWh}(0.097$ $\$ / \mathrm{kWh}$ ) and discount rate of $8 \%$, the NPV becomes negative when the installation cost is above 1499.76 $\$ / \mathrm{kW}$. At $8 \%$ discount rate and electricity price of 35
$\mathrm{N} / \mathrm{kWh}$, the NPV decreases with the operations and maintenance cost, and becomes negative when the operations and maintenance cost goes above 40.98 $\$ / \mathrm{MWh}$.

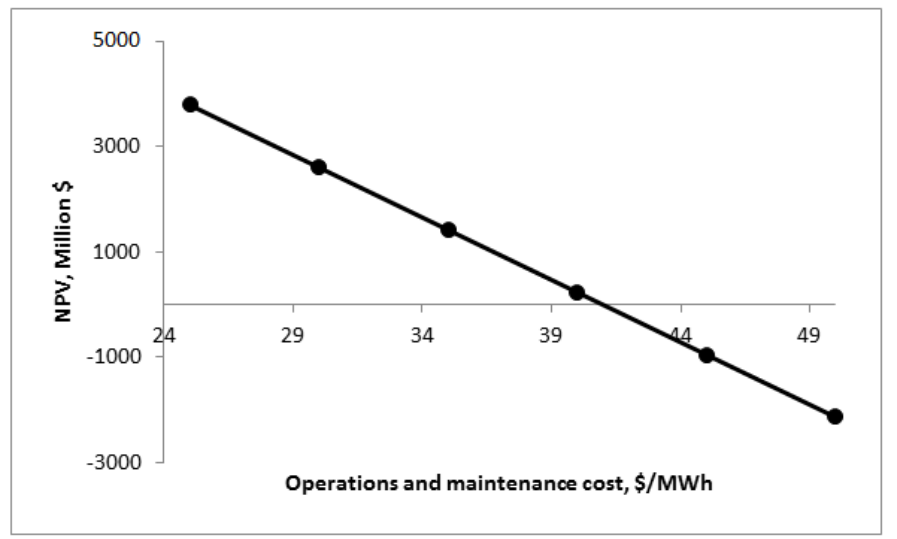

Fig-3: NPV against operations and maintenance cost at $8 \%$ discount rate

The points where the NPV becomes negative in Figures 2 and 3 are greatly influenced by the discount rate and the price of electricity. The NPV drops with discount rate but increases with the price of electricity as in Figures 4 and 5 respectively. Thus, if a discount rate greater than $8 \%$ is employed, the points where the NPV becomes negative will shift to the left in Figures 2 and 3. On the other hand, if the price of electricity is increased, the above points will shift to the right in the respective figures.
From Figure-4, the NPV is zero around discount rate of $11.209 \%$ (this is the internal rate of return). The NPV against electricity price in Figure-5 is obtained at discount rate of $8 \%$ and the NPV increases with electricity price and becomes positive when the electricity price goes above $\$ 29.95$. This value depends on the discount rate used. If the discount rate is $16 \%$, the electricity price to get positive NPV is around N43.20.

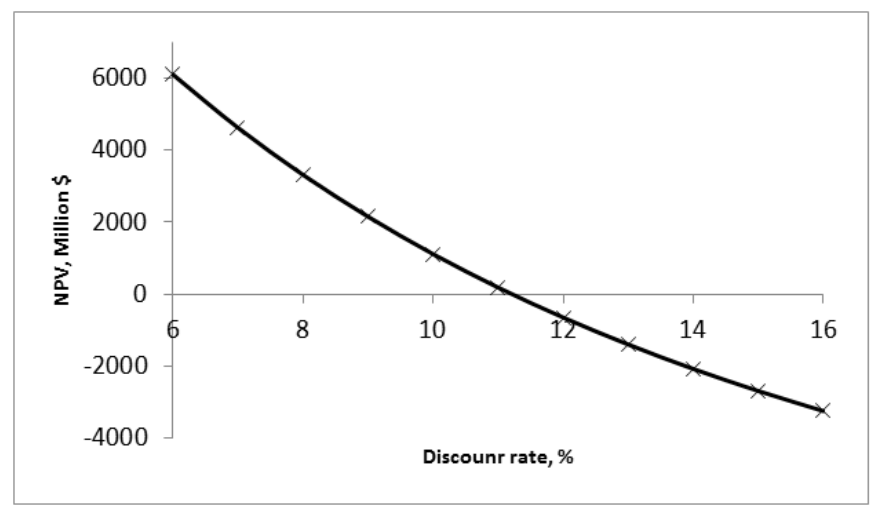

Fig-4: NPV against discount rate

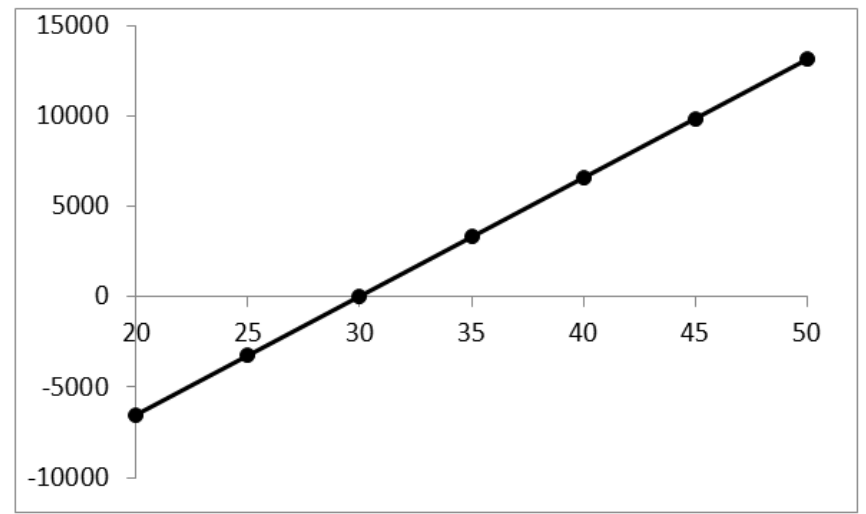

Fig-5: NPV against electricity price at $8 \%$ discount 
From the above, if wind energy is to be exploited as a source of electricity for Lagos state, the price of electricity should be above 43.20 if the project is funded at a discount rate of $16 \%$. The cash flow and the NPV for wind energy system at $8 \%$ discount rate for Lagos state is shown in Table-4. The discounted payback period of the project can be easily obtained from cash flow if it is needed. Similar analysis could be done for other states.

Table-4: Cash flow and NPV of wind energy system for Lagos state

\begin{tabular}{|c|c|c|c|c|c|c|c|c|c|c|c|c|}
\hline Parameter & & & & & Year & & & & & & Total & NPV \\
\hline & 1 & 3 & 5 & 7 & 9 & 11 & 13 & 15 & 17 & 20 & & \\
\hline $\begin{array}{l}\text { Installed Cost (Million } \\
\$)\end{array}$ & $\begin{array}{l}- \\
13254 \\
.15\end{array}$ & 0 & 0 & 0 & 0 & 0 & 0 & 0 & 0 & 0 & $\begin{array}{l}- \\
13254 \\
.15\end{array}$ & \\
\hline NACF (Million \$) & $\begin{array}{l}1687 . \\
19\end{array}$ & $\begin{array}{l}1687 \\
.19\end{array}$ & $\begin{array}{l}1687 \\
.19\end{array}$ & $\begin{array}{l}1687 \\
.19\end{array}$ & $\begin{array}{l}1687 . \\
19\end{array}$ & $\begin{array}{l}1687 . \\
19\end{array}$ & $\begin{array}{l}1687 . \\
19\end{array}$ & $\begin{array}{l}1687 . \\
19\end{array}$ & $\begin{array}{l}1687 . \\
19\end{array}$ & $\begin{array}{l}1687 . \\
19\end{array}$ & $\begin{array}{l}33743 \\
.84\end{array}$ & \\
\hline Discount factor at $8 \%$ & 0.93 & 0.79 & 0.68 & 0.58 & 0.50 & 0.43 & 0.37 & 0.32 & 0.27 & 0.21 & & \\
\hline $\begin{array}{l}\text { Discounted NACF (M } \\
\$)\end{array}$ & $\begin{array}{l}1562 . \\
21\end{array}$ & $\begin{array}{l}1339 \\
.35\end{array}$ & $\begin{array}{l}1148 \\
.27\end{array}$ & $\begin{array}{l}984 . \\
46\end{array}$ & $\begin{array}{l}844.0 \\
2\end{array}$ & $\begin{array}{l}723.6 \\
1\end{array}$ & $\begin{array}{l}620.3 \\
8\end{array}$ & $\begin{array}{l}531.8 \\
7\end{array}$ & $\begin{array}{l}456.0 \\
0\end{array}$ & $\begin{array}{l}361.9 \\
8\end{array}$ & $\begin{array}{l}16565 \\
.10\end{array}$ & $\begin{array}{l}3310 \\
.95\end{array}$ \\
\hline $\begin{array}{l}\text { Cumulative discounted } \\
\text { NACF (M \$) }\end{array}$ & $\begin{array}{l}1562 . \\
21\end{array}$ & $\begin{array}{l}4348 \\
.06\end{array}$ & $\begin{array}{l}6736 \\
.47\end{array}$ & $\begin{array}{l}8784 \\
.15\end{array}$ & $\begin{array}{l}1053 \\
9.70\end{array}$ & $\begin{array}{l}1204 \\
4.80\end{array}$ & $\begin{array}{l}1333 \\
5.19\end{array}$ & $\begin{array}{l}1444 \\
1.48\end{array}$ & $\begin{array}{l}1538 \\
9.96\end{array}$ & $\begin{array}{l}1656 \\
5.10\end{array}$ & & \\
\hline
\end{tabular}

For the solar energy utilization, the capacity factor, the solar energy to be installed and the area to be covered by the solar panels per MW of energy demand in the selected 6 locations are presented in Table-5. Bornu has the highest solar radiation and hence the most suitable location for solar PV system. The solar energy to be installed depends on the capacity factor and the energy demand, and it is closer to the energy demand for higher values of capacity factor. The higher the capacity factor the lower the area required for solar panels installation per unit energy demand.

Table-5: Solar energy parameters of the selected states

\begin{tabular}{|l|l|l|l|l|l|}
\hline States & $\begin{array}{l}\text { Solar radiation, } \\
\mathbf{k W h} / \mathbf{m}^{\mathbf{2}} / \mathbf{d a y}\end{array}$ & $\begin{array}{l}\text { Capacity } \\
\text { factor }\end{array}$ & $\begin{array}{l}\text { Energy } \\
\text { demand, } \mathbf{M W}\end{array}$ & $\begin{array}{l}\text { Solar energy } \\
\text { installation, } \mathbf{M W}\end{array}$ & $\begin{array}{l}\text { Area of panels per energy } \\
\text { demand, } \mathbf{~}^{\mathbf{2}} / \mathbf{M W}\end{array}$ \\
\hline Oyo & 4.71 & 0.1472 & 855.67 & 5813.45 & 6794.06 \\
\hline Rivers & 4.31 & 0.1347 & 1035.50 & 7688.17 & 7424.59 \\
\hline Enugu & 4.82 & 0.1506 & 136.86 & 908.64 & 6639.00 \\
\hline Sokoto & 5.34 & 0.1669 & 191.80 & 1149.37 & 5992.51 \\
\hline Kwara & 5.23 & 0.1634 & 90.09 & 551.22 & 6118.55 \\
\hline Bornu & 6.40 & 0.2000 & 218.35 & 1091.77 & 5000.00 \\
\hline
\end{tabular}

The NPV and the LCOE for project duration of 20 years is presented in Table 6 for $8 \%$ and $16 \%$ discount rates. The NPVs are all negative for $16 \%$ discount rate. At $8 \%$ discount rate, only the NPV for Bornu is positive, suggesting that only Bornu is economically viable for solar PV system based on the present installation cost, operations and maintenance cost and price of electricity. There is no much difference between the LCOE obtained at $8 \%$ and $16 \%$ discount rates when energy is not discounted because the annual operation and maintenance cost which is discounted is very low compared to that in wind energy system. The LCOE values are comparatively higher than those from the wind energy system for most of the locations. Higher electricity price is needed for suitable utilization of utility scale solar PV system at $8 \%$ discount rate in the other locations aside Bornu state.

Table-6: NPV and LCOE for solar PV system at $16 \%$ and $8 \%$ interest rates

\begin{tabular}{|l|l|l|l|l|l|l|}
\hline \multirow{3}{*}{ State } & NPV (Million \$) & \multicolumn{2}{l|}{ LCOE (\$/kWh) } & \multicolumn{2}{l|}{ At 16\% DR } \\
\cline { 4 - 7 } & & & \multicolumn{2}{|l|}{ At 8\% DR } & \\
\cline { 3 - 7 } & At 8\% DR & At 16\% DR & Energy und. & Energy dis. & Energy und. & Energy dis \\
\hline Oyo & -1343.28 & -4127.35 & 0.0566 & 0.1152 & 0.0563 & 0.1898 \\
\hline Rivers & -2565.81 & -5934.99 & 0.0617 & 0.1258 & 0.0615 & 0.2073 \\
\hline Enugu & -184.30 & -629.61 & 0.0553 & 0.1126 & 0.0550 & 0.1855 \\
\hline Sokoto & -79.72 & -703.78 & 0.0500 & 0.1018 & 0.0497 & 0.1676 \\
\hline Kwara & -53.80 & -346.92 & 0.0510 & 0.1039 & 0.0507 & 0.1711 \\
\hline Bornu & 221.32 & -489.14 & 0.0418 & 0.0852 & 0.0415 & 0.1401 \\
\hline
\end{tabular}

dis. $=$ discounted und $=$ undiscounted 
Ebigenibo Genuine Saturday \& Oluwasanmi Adeshina Aderibigbe; Saudi J Eng Technol, Dec, 2020; 5(12): 524-535

Using Rivers state as a case study, the variation of the NPV against electricity price at $8 \%$ discount rate is shown in Figure 6. The NPV is negative until the electricity price is above $\$ 45.40(0.1258 \$$ ) per $\mathrm{kWh}$. The price of electricity at which the NPV is positive is lower than the average price of electricity in both the UK and the USA. Thus, at $8 \%$ discount rate, solar PV utilization can be pursued on utility scale at electricity price above $\$ 45.40$ in Rivers state, although, it will be difficult and unreasonable to push for electricity prices in Nigeria to be as high as those in the UK or USA because the average worker in Nigeria earns much lower. The variation of NPV against installation cost at $8 \%$ discount rate and electricity price of $45 \mathrm{~N} / \mathrm{kWh}$ is presented in Figure-7 for Rivers state. At this electricity price, the NPV is positive until the installation cost is above $1427.1 \$ / \mathrm{kW}$. Similar analysis could be made for the other locations.

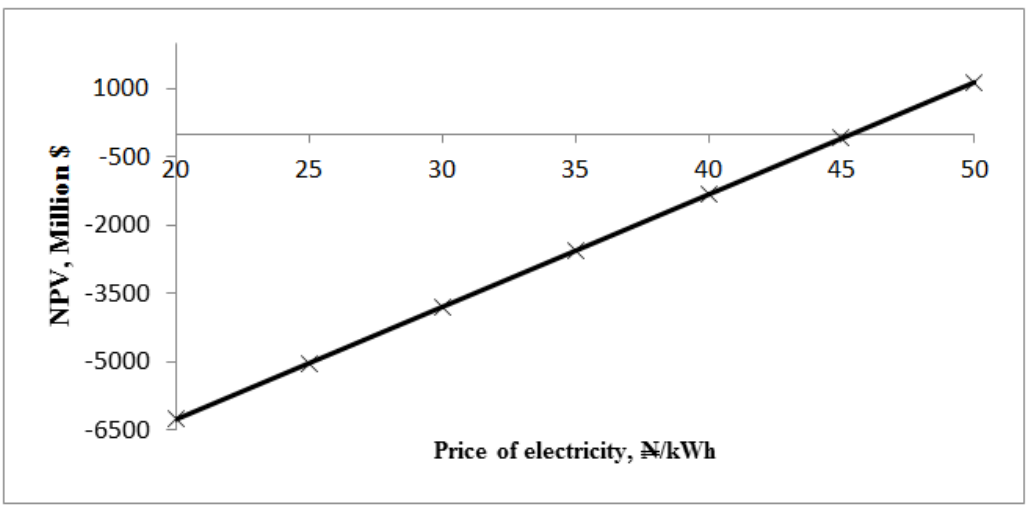

Fig-6: NPV against electricity price at $8 \%$ discount rate

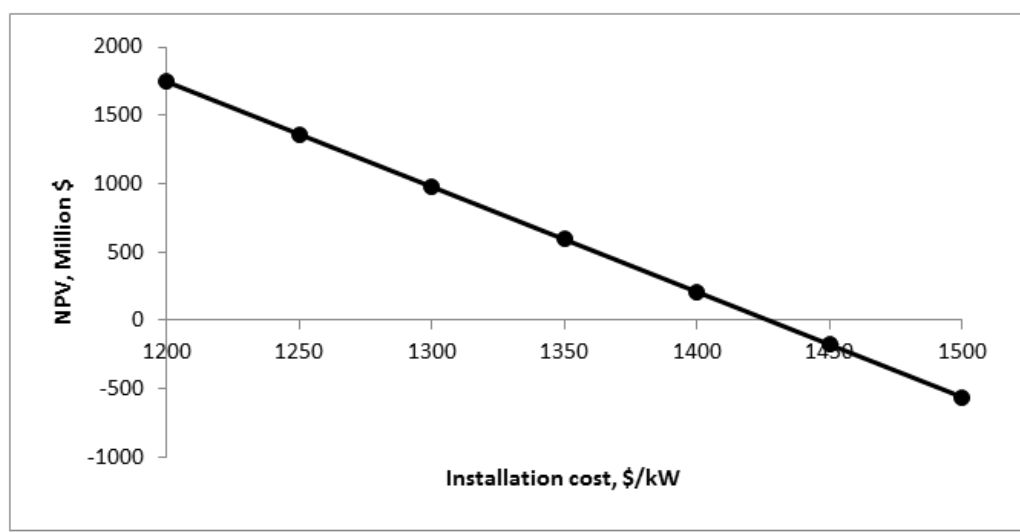

Fig-7: NPV against installation cost at $8 \%$ discount rate and electricity price at $45 \mathrm{~N} / \mathrm{kWh}$

The cash flow and the NPV for 20 years project duration is presented in Table-7 for Rivers state at $8 \%$ discount rate and electricity price of $46 \mathrm{~N} / \mathrm{kWh}$.
Although the NPV is positive, the discounted payback period is above 18 years which is quite high.

Table-7: Cash flow and NPV of solar energy system for Rivers state.

\begin{tabular}{|c|c|c|c|c|c|c|c|c|c|c|c|c|}
\hline Parameter & Year & & & & & & & & & & Total & NPV \\
\hline & 1 & 3 & 5 & 7 & 9 & 11 & 13 & 15 & 17 & 20 & & \\
\hline $\begin{array}{l}\begin{array}{l}\text { Installed } \quad \text { Cost } \\
(\mathrm{M} \$)\end{array}\end{array}$ & $\begin{array}{l}- \\
11070 . \\
96 \\
\end{array}$ & 0 & 0 & 0 & 0 & 0 & 0 & 0 & 0 & 0 & $\begin{array}{l}- \\
11070 . \\
96\end{array}$ & \\
\hline NACF (M\$) & $\begin{array}{l}1142.6 \\
7\end{array}$ & $\begin{array}{l}1142 . \\
67\end{array}$ & $\begin{array}{l}1142 . \\
67\end{array}$ & $\begin{array}{l}1142 . \\
67\end{array}$ & $\begin{array}{l}1142 . \\
67\end{array}$ & $\begin{array}{l}1142 . \\
67\end{array}$ & $\begin{array}{l}1142 . \\
67\end{array}$ & $\begin{array}{l}1142 . \\
67\end{array}$ & $\begin{array}{l}1142.6 \\
7 \\
\end{array}$ & $\begin{array}{l}1142.6 \\
7 \\
\end{array}$ & $\begin{array}{l}22853 . \\
39\end{array}$ & \\
\hline $\begin{array}{l}\text { Discount factor at } \\
8 \%\end{array}$ & 0.93 & 0.79 & 0.68 & 0.58 & 0.50 & 0.43 & 0.37 & 0.32 & 0.27 & 0.21 & & \\
\hline $\begin{array}{l}\text { Discounted NACF } \\
(\mathrm{M} \$)\end{array}$ & $\begin{array}{l}1058.0 \\
3\end{array}$ & $\begin{array}{l}907.0 \\
9\end{array}$ & $\begin{array}{l}777.6 \\
8\end{array}$ & $\begin{array}{l}666.7 \\
4\end{array}$ & $\begin{array}{l}571.6 \\
2\end{array}$ & $\begin{array}{l}490.0 \\
7\end{array}$ & $\begin{array}{l}420.1 \\
6\end{array}$ & $\begin{array}{l}360.2 \\
2\end{array}$ & 308.83 & 245.16 & $\begin{array}{l}11218 . \\
90\end{array}$ & $\begin{array}{l}147 . \\
94\end{array}$ \\
\hline $\begin{array}{l}\text { Cumulative } \\
\text { discounted NACF } \\
(\mathrm{M} \$)\end{array}$ & $\begin{array}{l}1058.0 \\
3\end{array}$ & $\begin{array}{l}2944 . \\
77\end{array}$ & $\begin{array}{l}4562 . \\
35\end{array}$ & $\begin{array}{l}5949 . \\
16\end{array}$ & $\begin{array}{l}7138 . \\
13\end{array}$ & $\begin{array}{l}8157 . \\
48\end{array}$ & $\begin{array}{l}9031 . \\
41\end{array}$ & $\begin{array}{l}9780 . \\
66\end{array}$ & $\begin{array}{l}10423 . \\
02\end{array}$ & $\begin{array}{l}11218 . \\
90\end{array}$ & & \\
\hline
\end{tabular}


Ebigenibo Genuine Saturday \& Oluwasanmi Adeshina Aderibigbe; Saudi J Eng Technol, Dec, 2020; 5(12): 524-535

\section{CONCLUSION}

The economic implications of the utilization of wind energy for 12 locations and solar PV system for 6 locations for electricity generation in Nigeria was considered in this work by considering project duration of 20 years and estimating the NPV and the LCOE for each of the locations. When discount rates similar to the lending rates in Nigeria (16\% and above) are used together with the average existing electricity price for the wind energy systems, only 4 locations (Enugu, Kano, Katsina and Plateau states) out of the 12 locations gave positive NPV. But at $8 \%$ discount rate, the NPV is positive for 9 of the locations, while the remaining three locations with lowest wind speed still have negative NPV. When the LCOE is calculated without discounting the energy, the value obtained at $16 \%$ for any of the locations is smaller than that obtained at $8 \%$ which erroneously suggests it is better to operate the project at higher discount rates. LCOE should thus be calculated by also discounting the energy produced. When energy is discounted, the LCOE obtained is greater than that obtained when energy is not discounted. The LCOE in this case also increases with discount rate more rapidly than the rate at which it decreases with discount rate when energy is not discounted. For the solar PV system, both discount rates of $16 \%$ and $8 \%$ together with the existing electricity price suggest the project is viable for only one of the locations (Bornu) as every other location gave negative NPV for the 20 years project. The LCOE from the wind energy systems are comparatively lower than those from the solar PV systems. Thus, there are more prospects in the profitable utilization of wind energy system for electricity generation in many locations in Nigeria than solar energy utilization going by current installation as well as operations and maintenance cost values. Also, the price of electricity in Nigeria need to be higher than the present values for the utilization of wind and solar PV systems to be economically more viable.

\section{REFERENCES}

1. Ohunakin, S. O., Ojolo, S. J., Ogunsina, S. B., \& Dinrifo, R. R. (2012). Analysis of cost estimation and wind energy evaluation using wind energy conversion systems (WECS) for electricity generation in six selected high altitude locations in Nigeria. Energy policy, 48, 594-600.

2. Onyemechi, C., Igboanusi, C. C., \& Ezenwa, E. A. (2013). A logistic analysis of Nigeria's offshore windfarm sector. Int J Res Soc Sci, 4(4):88-91.

3. Oyedepo, S. O., Adaramola, M. S., \& Paul, S. S. (2012). Analysis of wind speed data and wind energy potential in three selected locations in south-east Nigeria. International Journal of Energy and Environmental Engineering, 3(1), 7.

4. Akpinar, E. K., \& Akpinar, S. (2005). An assessment on seasonal analysis of wind energy characteristics and wind turbine characteristics. Energy conversion and

management, 46(11-12), 1848-1867.

5. Dioha, M. O., \& Kumar, A. (2018). Rooftop solar PV for urban residential buildings of Nigeria: A preliminary attempt towards potential estimation. AIMS Energy, 6(5), 710.

6. Oghogho, I. (2014). Solar energy potential and its development fortainable energy generation in Nigeria: a road map to achieving this feat. International Journal of Engineering and Management Sciences, 5(2), 61-67.

7. Oji, J. O., Idusuyi, N., Aliu, T. O., Petinrin, M. O., Odejobi, O. A., \& Adetunji, A. R. (2012). Utilization of solar energy for power generation in Nigeria. International Journal of Energy Engineering, 2(2), 54-59.

8. Vincent-Akpu, I. (2012). Renewable energy potentials in Nigeria, in: 32nd Annu. Meet. Int. Assoc. Impact Assessment, 27 May- 1 June 2012, Cent. Congr. Da Alfândega, Porto - Port., 2012. http://large.stanford.edu/courses/2017/ph240/akere le1/docs/vincent-akpu.pdf [Accessed 23.05.2020].

9. Okafor, E. N. C., \& Joe-Uzuegbu, C. K. A. (2010). Challenges To Development Of Renewable Energy For Electric Power Sector In Nigeria. International journal of academic research, 2(2): 211-216.

10. Emodi, N. V., \& Boo, K. J. (2015). Sustainable energy development in Nigeria: Overcoming energy poverty. International Journal of Energy Economics and Policy, 5(2):580-597.

11. Bamisile, O., Dagbasi, M., Babatunde, A., \& Ayodele, O. (2017). A review of renewable energy potential in Nigeria; solar power development over the years. Engineering and Applied Science Research, 44(4), 242-248.

12. Sambo, A. S. (2005). Renewable energy for rural development: the Nigerian perspective. ISESCO Science and Technology Vision, 1(2005), 12-22.

13. Shaaban, M., \& Petinrin, J. O. (2014). Renewable energy potentials in Nigeria: Meeting rural energy needs. Renewable and Sustainable Energy Reviews, 29, 72-84.

14. Emodi, N. V., \& Yusuf, S. D. (2015). Improving electricity access in Nigeria: obstacles and the way forward. International Journal of Energy Economics and Policy, 5(1), 335-351.

15. Emodi, V. N., Yusuf, S. D., \& Boo, K. J. (2014). The necessity of the development of standards for renewable energy technologies in Nigeria. Smart Grid and Renewable Energy, 5(11), 259-274.

16. Oyedepo, S. O. (2014). Towards achieving energy for sustainable development in Nigeria. Renewable and sustainable energy reviews, 34, 255-272.

17. Sambo, A. S. (2009). Strategic developments in renewable energy in Nigeria. International Association for Energy Economics, 16(3), 15-19.

18. Adejumobi, I. A., Adebisi, O. I., \& Oyejide, S. A. (2013). Developing small hydropower potentials for rural electrification. International Journal of 
Research and Reviews in Applied Sciences, 17(1), $105-110$

19. Omojolaa, A., \& Oladejib, O. A. (2012). Small hydro power for rural electrification in Nigeria. American Journal of Science and Engineering, 1(2):29-34.

20. Ohunakin, O. S., Ojolo, S. J., \& Ajayi, O. O. (2011). Small hydropower (SHP) development in Nigeria: An assessment. Renewable and Sustainable Energy Reviews, 15(4), 2006-2013.

21. Rural Electrification Agency, Energizing Economies Initiative, Rural Electrif. Agency, Niger. (2020). https://rea.gov.ng/energizingeconomies/ (accessed May 17, 2020).

22. Akhator, P. E., Obanor, A. I., \& Sadjere, E. G. (2019). Electricity situation and potential development in Nigeria using off-grid green energy solutions. Journal of Applied Sciences and Environmental Management, 23(3), 527-537.

23. Alao, O., \& Awodele, K. (2018, June). An overview of the Nigerian power sector, the challenges of its national grid and off-grid development as a proposed solution. In 2018 IEEE PES/IAS PowerAfrica (pp. 178-183). IEEE.

24. Elusakin Julius, E., Olufemi, A. O., \& Chuks, D. J. (2014). Challenges of sustaining off-grid power generation in Nigeria rural communities. Afr. J. Eng. Res, 2, 51-57.

25. Briggs, T. A., Ugorji, K. (2017). Assessment of electricity demand and prediction model for the furture: Rivers State. Eur J Mech Res. 4:1-23. http://www.eajournals.org/wp-

content/uploads/Assessment-Of-Electricity-

Demand-and-Prediction-Model-For-The-Furture-

Rivers-State.pdf (accessed 2April 28, 2020).

26. Ditkovich, Y., \& Kuperman, A. (2014). Comparison of three methods for wind turbine capacity factor estimation. The Scientific World Journal, 2014: 1-7. https://doi.org/https://doi.org/10.1155/2014/80523 8.

27. Akorede, M. F., Ibrahim, O., Amuda, S. A., Otuoze, A. O., \& Olufeagba, B. J. (2017). Current status and outlook of renewable energy development in Nigeria. Nigerian Journal of Technology, 36(1), 196-212.

28. Gökçek, M., \& Genç, M. S. (2009). Evaluation of electricity generation and energy cost of wind energy conversion systems (WECSs) in Central Turkey. Applied Energy, 86(12), 2731-2739.

29. Saturday, E. G., \& Ebieto, E. C. (2019). Comparative Economic Analysis of Simple and Modified Cycle Gas Turbine Power Plants. Int J Sci Eng Res. 10:444-454. https://www.citefactor.org/journal/pdf/COMPAR ATIVE-ECONOMIC-ANALYSIS-OF-SIMPLEAND-MODIFIED-CYCLE-GAS-TURBINE-

PLANTS.pdf (accessed May 11, 2020).

30. NERC, Multi Year Tariff Order (MYTO) - 2015 for Benin Electricity Distribution Company (BEDC) for the Period 1st January 2015 to December 2024, ORDER NO. NERC/142.2, NERC, Nigeria, 2015. https://nerc.gov.ng/doclib/myto-2015/111-myto2015-benin-disco-tariff-order/file (accessed May 11, 2020).

31. Wind Power Monthly, Energy cost analysis 2020: Wind is ready for zero-subsidy future, (2020). https://www.windpowermonthly.com/article/1671 659/energy-cost-analysis-2020-wind-ready-zerosubsidy-future (accessed June 5, 2020).

32. Fu, R., Feldman, D., \& Margolis, R. (2018). US solar photovoltaic system cost benchmark: Q1 2018 , NREL. https://www.nrel.gov/docs/fy19osti/72399.pdf (accessed June 5, 2020).

33. Ukrainian Wind Energy Association, True cost of wind turbine operations and maintenance, UWEA. (2020). http://uwea.com.ua/article/realnayastoimost-ekspluatacii-i-obsluzhivaniyavetroturbiny/ (accessed June 5, 2020).

34. Kingmakers, 2020 state of states ranking, Kingmakers. (2020).

https://stateofstates.kingmakers.com.ng/ (accessed May 15, 2020). 